\title{
Teacher Recruitment Negotiations: A Form of Early Childhood Education Strategy in Indonesia
}

\author{
Inten Risna ${ }^{1, *}$, Maulida Nur ${ }^{2}$ \\ ${ }^{1}$ STIT Qurrota A'yun \\ ${ }^{2}$ Al-Mustaqim Kindergarten \\ *Corresponding author. Email: intenrisna22@gmail.com
}

\begin{abstract}
This paper aims to uncover the extent to which the recruitment of high-quality early childhood education teachers is still a challenge to date, especially in regions (villages/remote areas) in Indonesia. This article is based on the assumption that the professionalism of teachers is influenced by the teacher recruitment system at each institution. These researchers used a meta-analysis of research and previous literature on teacher recruitment for early childhood education. The findings of this article are expected to explain the extent to which early childhood education teacher recruitment campaigns overcome the challenges in recruiting. Selecting and hiring early childhood education staff by making the early childhood education sector an attractive choice.
\end{abstract}

Keywords: Recruitment of early childhood education teachers, early childhood education.

\section{INTRODUCTION}

Education is very important for human life, including the level of early childhood education (ECE). The government established the one village one ECE policy as stated in the Ministry of Education and Culture Regulation Number 18 of 2018 concerning early childhood education services in Indonesia. The ECE service policy was welcomed positively by various groups evidenced by those flocking to open ECE services and recruiting ECE teachers [1].

The number of early childhood education services is still a challenge today, especially in regions (villages / remote areas) in Indonesia. In some villages, managers accept anyone who wants to become an ECE teacher regardless of his background, qualifications, and competencies of prospective early childhood education teachers [2]. The most important aspect is that they are interested and willing to teach at a low salary regardless of the experience said prospective teachers, qualifications of prospective teachers or the competence of the teachers. Despite the fact that being a teacher is actually not an easy thing and they have to deal with early childhood students who are experiencing significant development [3].

Until now, there are still many teachers who have not met the expected professional competency standards [4]. This can be seen from the data obtained from basic data of educators from the national education department, in 2020 showing that in Indonesia the number of non-formal ECE teachers with bachelor degrees is 80,481 people, 13,147 with diplomas, 138,008 with senior high school education, and 26,382 with only junior high school education. Meanwhile, the education qualifications of teachers in formal ECE with bachelor degrees are 186,697 people, 18,711 people with diplomas, 67,998 with senior high school education and 7,450 with junior high school education.

From these data, it can be seen that there are still many teachers who have high school education qualifications and others with even only junior high school education qualifications, and clearly not in accordance with the regulation of the Ministry of Education and Culture Number 137 of 2014 concerning early childhood education standards that the academic qualifications of early childhood education teachers must have a diploma four (IV) or bachelor degree in the field of early childhood education or psychology obtained from an accredited study program [5].

Meanwhile, teachers have a profession that requires academic qualifications, competencies, and teacher certificates in accordance with the requirements for each specific type and level of education [6]. A teacher will determine performance, goal achievement and behaviour to obtain effective learning in order to achieve positive results [7]. Thus, teachers as determinants of educational success need a recruitment mechanism that can produce professional educational 
personnel candidates. Effective recruitment and selection will have a direct effect on teacher productivity and performance [8].

Based on the explanation above, the author intends to understand the extent of teacher recruitment in early childhood education as well as voicing the importance of good teacher recruitment, since effective selection will have a positive impact on educational institutions. This paper is based on literature research [9].

\section{RESULT AND DISCUSSION}

\subsection{Early Childhood Teacher Problems}

The teacher is a factor that determines the quality of education because the teacher deals directly with students in the learning process. In the hands of the teacher, the quality and personality of students are formed. The teacher is a running curriculum, no matter how good the existing curriculum and education system are, without the support of the teacher's ability, everything will be in vain [10]. On the other hand, many ECE institutions urge ECE managers to look for teachers as teaching staff so that this urgent need makes the teacher recruitment system no longer selected by competitive examinations but is judged only by the ability to fulfil the teaching mission temporarily [11], such as a recruitment technique in schools that is based on kinship to fill the gaps or teacher vacancies. This will indirectly have an impact on the acquisition of teachers who are not in accordance with the needs of the school, such as teachers who are less competent and do not have high integrity [12].

In addition, the Indonesian culture that places great importance on spirituality and mutual cooperation raises the perception that being a teacher is one way to devote oneself to God [13]. Low income is not a barrier to becoming a teacher because they have the perception that a teacher is a profession that is respected by society and has a high professional status so they see teaching as an honourable career choice [14]. Based on this thought, it seems that the basis for the voluntary system to become a teacher is without seeing further the background of the prospective teacher.

In this regard, recruiting and retaining teachers is still a challenge for schools in rural areas because schools in rural areas have relatively inadequate facilities, and geographic positions can make it difficult to recruit and maintain qualified teaching staff. This can exacerbate existing disparities by allowing disadvantaged regions to fail to attract and recruit good candidates [11].

\subsection{Recruitment Urgency}

Recruitment is the process of finding, finding and attracting competent applicants to be employed in an organization [15]. The teacher admission mechanism should receive the main attention because at this stage of acceptance it can select prospective teachers according to the desired criteria for the ideals and goals of education to be achieved. Mistakes in teacher selection can have fateful consequences for the continuity of learning activities in relation to achieving the desired goals and ideals of graduates. Problems that occur in an educational institution are often due to the performance of teachers that is not as expected. This can be caused by inadequate teacher recruitment planning resulting in teachers who are not experts in their fields which is one of the obstacles in realizing the goals of education and the educational institution itself [16].

Recruitment has a positive and significant effect on performance. Thus, the better the implementation of the recruitment system, the higher the performance. A comprehensive teacher selection system does require a lot of money, but research shows that these costs are relatively small compared to the possible benefits [17]. A good recruitment system will benefit all including students, institutions and teachers themselves. Recruitment is an important step in selecting teachers with the desired profile according to a professional frame of reference. Below are 4 stages in preparing teacher recruitment according to Tournier [11]:1) Identification of needs, at this early stage the manager determines the needs of teachers in schools, what kind of teacher and what teachers wants; 2) decide the profile, which is done at this stage, namely identifying skills, experience and knowledge, and the academic level; 3) the next stage, namely selection, at this stage the manager ensures that a teacher must have important aspects, namely the quality of social relationships, behaviour and attitudes, motivation and cognitive abilities. At this stage, competitive tests, interview tests and teaching practice can be used; 4) and the last stage, namely recruiting teachers.

\subsection{Active Campaigns as a Recruitment Strategy}

Active campaigns are often carried out to achieve the desired goals, including the process of recruiting early childhood education teachers. This active campaign is carried out in attracting prospective teachers so that they desire to become ECE teachers who are balanced with qualified abilities. Such is the case especially in ECE service institutions located in remote areas. By making early childhood education an attractive career choice, it is the key to the emergence of motivation to be in this field [18]. 
The strategy that can be taken to make ECE an attractive career choice is to offer financial benefits [19], [20], [3], [21], scholarships for education/ training [22], [23], [24] and media campaigns to raise public awareness [25], [26], [27].

\subsubsection{Improving the Social Status of the Early Childhood Teacher Profession by Offering Financial Benefits}

Financial benefits can allow them to stay in choosing their profession. Many studies have shown that teacher salaries can affect teacher supply in terms of quality and quantity [28], [29], [30].

Kilgallon, Maloney, Lock [30] revealed that financial gain / salary is a key factor in difficulties in recruiting staff due to a shortage of applicants [31]. The shortage of applicants is due to services being paid at low wages and poor conditions [32]. In addition, the main reasons for teachers to leave the profession are lack of comparative promotion prospects, low status, and unfavourable employment [33].

Other studies have shown that improving teacher quality is not only through education and training, but working conditions are also an important factor affecting teacher behaviour and performance [34], [35], [36], [37]. These working conditions include salary and benefits related to work [38]. Salaries and allowances are extrinsic factors that affect teacher career choices, which are to generate great motivation to work and increase their professionalism [3] and increase their support in teaching [31].

Teachers tend to choose to quit when they are working for low wages. This is what affects the reduction in interest in becoming a teacher [30], [29], [39], [40] so that with increased financial gain / salary earned can increase attractiveness as a career choice for early childhood teachers [21].

\subsubsection{Funding Teacher Education and Training Programs (Scholarships)}

Education and training programs for teachers or prospective teachers that are fully or partially funded, and lowering costs for education can increase the attractiveness of teaching and teacher professional programs [26]. Podolsky \& Kini [40] revealed that providing scholarships is an effective strategy in attracting and preparing candidates' abilities and recruiting them to the place or field where they are needed [41].

In line with this, based on Ackerman study found that assistance / scholarships given to teachers can increase their credibility and professionalism [24]. Without financial assistance / scholarships for ECE educators, teachers will find it difficult to increase their credibility due to the low salary they receive [22]. They are prevented from participating in training because of the costs involved [42]; so that support specifically related to quality improvement in the ECE sector is urgently needed. Scholarships are also proven to be able to improve the learning achievement of students from lower socioeconomic classes so that they can catch up with students from middle socioeconomic class [43], [44], [45].

Thus, the initial education program, which is fully or partially funded, can increase the attractiveness of teaching programs, including the teaching profession.

\subsubsection{Media Campaigns to Raise Public Awareness}

The media is a tool to attract staff and increase public awareness about early childhood education by providing information regarding ECE services, promoting that ECE at the early years of life has an important role to play, and offers a means of sharing the fun experiences of being an ECE teacher [26]. One effective way is inviting prospective teachers to school to attend workshops, exhibitions or competitions [14].

In the UK, on a website, "Getting into Teaching" was created specifically to attract staff. The site provides information on how to register for teaching and professional programs and emphasizes the importance of teaching. Through the information obtained, one can change his/her career choices, namely self-confidence, an attitude of wanting to learn and a willingness to enter the teaching profession [27], [20].

\section{CONCLUSION}

Coordinated recruitment is an essential condition for the provision of quality education. The campaign to recruit ECE teachers is to make the early childhood education sector an attractive option. However, carrying out teacher recruitment is not easy, it requires a variety of careful preparations so that the recruitment process is carried out effectively. The teacher recruitment system requires a good strategy, the better the recruitment process, the more likely it is to get the right teacher.

\section{RECOMMENDATION}

When the teacher has undergone a series of selections and the demands are met, such as qualifications and favourable test results, the government should help recruitment agencies and teachers by making it easy for teachers to obtain financial allowances, one of which is certification costs. From the author's experience as a teacher, it is quite difficult for teachers to find because they have to meet several stages starting from getting teacher identification number after at least 2 years of teaching, then after 
getting this teacher identification number, new teachers can take part in the pretest selection which is not easy (pass/fail). If the teacher passes the pretest the teacher can continue to the next stage, namely Professional Teacher Program. Then if the teacher does not pass, the teacher must return to the selection next year and will continue to repeat this process until the teacher passes. This is usually a frightening aspect and deterrence for prospective teachers to be interested in working in the ECE teacher sector.

\section{REFERENCES}

[1] OECD. Starting Strong IV: Monitoring quality in early childhood education and care. Paris: OECD Publishing; 2015.

[2] OECD. Attracting, developing and retaining eeffective teachers. Paris: OECD Publishing; 2003.

[3] Harms B, Knobloch N. Preservice teachers' motivation and leadership behaviours related to career choice. Career and Technical Education Research. 2005;30(2):101-24. DOI: 10.5328/cter30.2.101.

[4] Qomario Q, Kurniasih S, Anggraini H. Studi analisis latar belakang pendidikan, sertifikasi guru dan usia guru paud di kota Bandar Lampung berdasarkan hasil nilai Uji Kompetensi Guru (UKG). Jurnal Caksana: Pendidikan Anak Usia Dini. 2018;1(2):81-101.

[5] Ministry of Education and Culture of the Republic Indonesia. Standar nasional pendidikan anak usia dini. UU No. 137 Tahun 2014 [Internet]. 2014.13p. Available from: https://anggunpaud.kemdikbud. go.id/index.php/berita/index/20160916130826/Per mendikbud-No-137-Tahun-2014-Tentang-StandarNasional-PAUD

[6] Suryana D. Profesionalisme guru pendidikan anak usia dini berbasis peraturan Menteri No. 58 Tahun 2009. Pedagogi: Jurnal Ilmiah Ilmu Pendidikan. 2013;13(2):53-61.

[7] Aliakbari M, Darabi R. On the relationship between efficacy of classroom management, transformational leadership style, and teachers' personality. Procedia-Social and Behavioral Sciences. 2013;93:1716-21.

[8] Rony R. Sistem Rekrutmen Tenaga Pendidik (Guru). MIYAH: Jurnal Studi Islam. 2019;14(2):37-57.

[9] Glass GV. Primary, secondary, and meta-analysis of research. Educational researcher. 1976;5(10):3-8.

[10]Gaffar MF. Guru sebagai profesi. Jurnal Administrasi Pendidikan [Internet]. 2017;5(1). Available from: https://ejournal.upi.edu/index.php /JAPSPs/ article/view/6177/4171
[11] Tournier B. Modules on Recruitment and teacher training: Issues and options [Internet]. Paris: IIEPUNESCO; 2015. Available from: http://www.iiep.unesco.org/en/training-modulesteacher-management-3337.

[12] Muspawi M, Rahmalia R, Hendra R, Rahman KA. Policy and practice: Teacher recruitment in private vocational schools based on regional potential. In Proceedings of the 3rd International Conference on Research of Educational Administration and Management (ICREAM 2019); 2020.

[13] Munandar S. Ilmu budaya dasar suatu pengantar Yogyakarta: Refika Aditama; 1998.

[14] Umayahara M, Lanceta AC, Krausz T. South East Asian guidelines for early childhood teacher: Development and management. Bangkok: SEAMEO Secretariat and UNESCO; 2016.

[15] Mondy WR, Noe R. Human resource management New Jersey: Pearson Education; 2010.

[16] Amalia P. Strategi rekrutmen tenaga pendidik dan kependidikan pada SDIT Darul Muttaqien Parung Bogor [Bachelor Thesis, Universitas Islam Negeri Syarif Hidayatullah]. Jakarta: UIN Syarif Hidayatullah; 2010.

[17] Jacob BA. The power of teacher selection to improve education. Evidence Speaks Reports. 2016 Mar 11;1(12):1-7.

[18]König J, Rothland M. Motivations for choosing teaching as a career: Effects on general pedagogical knowledge during initial teacher education. AsiaPacific Journal of Teacher Education. 2012;40(3):289-315 DOI: $10.1080 / 1359866 X$ 2012.700045 .

[19]Nolan A, Rouse E. Where to from here? Career choices of pre-service teachers undertaking a dual early childhood/primary qualification. Australian journal of teacher education. $2013 \mathrm{Jan} ; 38(1): 1-10$.

[20] Torquati JC, Raikes H, Huddleston-Casas CA. Teacher education, motivation, compensation, workplace support, and links to quality of centerbased child care and teachers' intention to stay in the early childhood profession. Early Childhood Research Quarterly. 2007;22(2):261-75.

[21]Nelson J. The childcare economic conundrum: Quality versus affordability. In: Moe KS, editor. Women, Family, and Work: Writings on the Economics of Gender. Melbourne: Blackwell; 2003. pp.125-41.

[22] Ackerman DJ. States' efforts in improving the qualifications of early care and education teachers. Educational Policy. 2004 May;18(2):311-37. DOI: $10.1177 / 0895904803262145$.

[23] Montilla MD. Models for increasing child care worker compensation. Washington DC: The Urban 
Institute; 2001.

[24] Vecchiotti S. Career development and universal prekindergarten: What now? what next? working paper series. New York: Foundation for Child Development; 2001. Available from: http//www.ffcd. org/ vecchiotti.pdf.

[25]Litjens I, Taguma M. Early childhood education and care staff recruitment and retention: A review for Kazakhstan. Kazakhstan: OECD; 2017.

[26] Nolan A, Rouse E. Where to from here? Career choices of pre-service teachers undertaking a dual early childhood/primary qualification. Australian Journal of Teacher Education. 2013;38(1):1-10. DOI: $10.14221 /$ ajte.2013v38n1.8.

[27] Adamson F, Darling-Hammond L. Funding disparities and the inequitable distribution of teachers: Evaluating sources and solutions. Education Policy Analysis Archives. 2012;20:1-46. DOI: 10.14507/epaa.v20n37.2012.

[28] Grissom JA, Viano SL, Selin JL. Understanding employee turnover in the public sector: Insights from research on teacher mobility. Public Administration Review. 2016;76(2):241-51. DOI: 10.1111/puar.12435.

[29]Loeb S, Darling-Hammond L, Luczak J. How teaching conditions predict teacher turnover in California schools. Peabody Journal of Education. 2005 Jul 1;80(3):44-70. DOI: 10.1207/s15327930p je8003_4.

[30] Kilgallon P, Maloney C, Lock G. Early childhood teachers' sustainment in the classroom. Australian Journal of Teacher Education. 2008;33(2):40-54 DOI: $10.14221 /$ ajte.2008v33n2.3.

[31]Brennan D. Child care and Australian social policy. In: Bowes J, Grace R, editors. Children, Families and Communities: Contexts and Consequences. South Melbourne: Oxford University Press; 2009. pp. 205-218.

[32]Chui Seng YB. Factors that determine the attractiveness of the teaching profession in Brunei Darussalam as perceived by teacher trainees. Journal of Education and teaching. 1994;20(1):11326. DOI: 10.1080/026074794020 0112.

[33] Howes C, James J, Ritchie S. Pathways to effective teaching. Early Childhood Research Quarterly. 2003 Mar 1;18(1):104-20 DOI: 10.1016/S08852006(03)00008-5.

[34]Hyson M, Tomlinson HB, Morris CA. Quality improvement in early childhood teacher education: Faculty perspectives and recommendations for the Future. Early Childhood Research \& Practice. 2009;11(1):1-17.

[35]Barnett WS. Better teachers, better preschools: Student achievement linked to teacher qualifications. NIEER Preschool Policy Matters. 2003;(2):1-13.

[36] Sommer D, Samuelsson IP, Hundeide K. Child perspectives and children's perspectives in theory and practice. London: Springer Science \& Business Media; 2009.

[37] Organization for Economic Co-operation and Development. Starting strong: A Quality Toolbox for Early Childhood Education and Care. Paris: OECD; 2011.

[38] Stockard J, Lehman MB. Influences on the satisfaction and retention of 1st-year teachers: The importance of effective school management. Educational Administration Quarterly. 2004;40(5):742-71. DOI: 10.1177/0013161X04268 844.

[39] Burgess S, Ratto M. The role of incentives in the public sector: Issues and evidence. Oxford Review of Economic Policy. 2003;19(2):285-300. DOI: 10.1093/oxrep/19.2.285

[40] Podolsky A, Kini T, Darling-Hammond L. Does teaching experience increase teacher effectiveness? A review of US research. Journal of Professional Capital and Community. 2019;4(4):286-308. DOI: 10.1108/JPCC-12-2018-00 32.

[41]Bertram T, Pascal C. Thematic review of early childhood education and care: Background report for the United Kingdom. London: Department for Education and Employment; 1999.

[42] Manhas S, Qadiri F. A comparative study of preschool education in early childhood education centres in India. Contemporary Issues in Early Childhood. 2010 Dec;11(4):443-7. DOI: 10.2304/ ciec.2010.11.4.443.

[43]Liyana LC. Pengaruh pelaksanaan program bantuan beasiswa anak pemulung terhadap motivasi berprestasi anak di sekolah alam Tunas mulia 'portal infaq' Bantar Gebang kota Bekasi [Bachelor Thesis, Universitas Pasundan]. Bandung: UNPAS; 2017.

[44] Utomo P. Analisis kontribusi pemberian beasiswa terhadap peningkatan prestasi akademik mahasiswa fakultas Teknik Universitas Negeri Yogyakarta. Jurnal Pendidikan Teknologi dan Kejuruan. 2011 May 1;20(1):67-87.

[45] Nurjannah H. Peran beasiswa unit bantuan sosial masyarakat Yayasan Haji Anif dalam memberdayakan masyarakat Islam di kota Medan Sumatera Utara [Doctoral Dissertation, Universitas Islam Negeri Sumatera Utara). Medan: UISU; 2018 . 